\title{
STRATEGIES FOR THE PREVENTION OF FACIAL PRESSURE INJURIES CAUSED BY THE USE OF THE PRONE POSITION
}

\author{
Larissa de Lima Machado Bandeira ${ }^{1, *} \mathbb{E}$, Sarah Maria Osório de Carvalho² $\mathbb{E}$, Layane Raquel \\ Ribeiro Calaça ${ }^{3}$ (D), Geysa Maria dos Santos Rabelo (D), Wesley Caio Ferreira Barbosa ${ }^{4}$ (D, \\ Bruno Abílio da Silva Machado ${ }^{4}$ (D), Josiane Santos Silva 5 (i)
}

\begin{abstract}
Objective: Identify the main strategies for preventing facial pressure injuries caused by the use of the prone position. Methods: Integrative literature review, carried out during the month of March 2021. Articles were searched in the MEDLINE, LILACS, BDENF and IBECS databases. The selected articles were written in English, Portuguese and Spanish, between 2016 and 2021. Duplicates and those that did not include the topic addressed were excluded. Initially, 29 articles were identified. After applying the inclusion and exclusion criteria, 10 articles resulted for analysis. Results: Of the complications related to the use of the prone position, 10 (100\%) of the studies address the pressure injury as the main complication of this therapeutic maneuver. As for prevention strategies, the studies analyzed cite the change in position associated with the use of pads and hydrocolloids as the main preventive methods. Conclusion: The following strategies to prevent facial pressure injury by using the prone position were identified: change of decubitus at pre-established times; use of devices that provide relief from pressure points, such as pads and hydrocolloids; and the use of low-cost and easily accessible materials, such as adapted surgical sponges, respecting the anatomical structures of each patient.
\end{abstract}

DESCRIPTORS: Prone position. Pressure injury. Prevention of diseases. Stomatherapy.

\section{ESTRATÉGIAS DE PREVENÇÃO DE LESÕES POR PRESSÃO FACIAL OCASIONADAS PELO USO DA POSIÇÃO PRONA}

\section{RESUMO}

Objetivo: Identificar as principais estratégias para prevenção de lesões por pressão faciais ocasionadas pelo uso de posição prona. Métodos: Revisão integrativa de literatura, realizada durante o mês de março de 2021. Foram pesquisados artigos nas bases de dados da MEDLINE, LILACS, BDENF e IBECS. Os artigos selecionados foram redigidos nos idiomas inglês, português e espanhol, entre 2016 e 2021. Foram excluídos os duplicados e os que não incluíam a temática abordada. Inicialmente, foram identificados 29 artigos. Após a aplicação dos critérios de inclusão e exclusão, resultaram 10 artigos para análise. Resultados: Das complicações relacionadas ao uso de posição prona, 10 (100\%) dos estudos abordam a lesão por pressão como a principal complicação dessa manobra terapêutica. Quanto às estratégias de prevenção, os estudos analisados citam a mudança de decúbito

1. Faculdade Estácio de Teresina - Departamento de Enfermagem - Teresina (PI) Brazil.

2. Centro Universitário Santo Agostinho - Departamento de Enfermagem - Teresina (PI) Brazil.

3. Centro Universitário Uninovafapi - Departamento de Enfermagem - Teresina (PI) Brazil.

4. Faculdade Maurício de Nassau - Departamento de Enfermagem - Teresina (PI) Brazil.

5. Universidade Estadual do Piauí - Departamento de Enfermagem - Teresina (PI) Brazil.

*Correspondence author: larissabandeiraphb@gmail.com

Section Editor: Manuela M F Coelho

Received: Mai. 2021, 04 | Accepted: Jul. 2021, 04

How to cite: Bandeira LLM; Carvalho SMO; Calaça LRR; Rabelo GMS; Barbosa WCF; Machado BAS; Silva JS. Strategies for the prevention of facial pressure injuries caused by the use of the prone position. ESTIMA, Braz. J. Enterostomal Ther., 2021, 19: e2021. https://doi.org/10.30886/estima.v19.1092_IN 
associada ao uso de coxim e hidrocolóides como principais métodos preventivos. Conclusão: Foram identificadas as seguintes estratégias de prevenção de lesão por pressão facial pelo uso de posição prona: mudança de decúbito em tempos pré-estabelecidos; uso de dispositivos que proporcionam alívio de pontos de pressão, tais como os coxins e hidrocolóides; e a utilização de materiais de baixo custo e fácil acesso, como esponjas cirúrgicas adaptadas, respeitando as estruturas anatômicas de cada paciente.

DESCRITORES: Decúbito ventral. Lesão por pressão. Prevenção de doenças. Estomaterapia.

DESCRIPTORS: Prone position. Pressure injury. Prevention of diseases. Stomatherapy.

\title{
ESTRATEGIAS DE PREVENCIÓN DE LESIONES POR PRESIÓN FACIAL OCASIONADAS POR EL USO DE LA POSICIÓN PRONA
}

\begin{abstract}
RESUMEN
Objetivo: Identificar las principales estrategias para la prevención de lesiones por presión faciales ocasionadas por el uso de posición prona. Métodos: Revisión integrativa de literatura, realizada durante el mes de marzo del 2021. Fueron investigados artículos en las bases de datos de MEDLINE, LILACS, BDENF e IBECS. Los artículos seleccionados fueron redactados en los idiomas inglés, portugués y español, entre el 2016 y el 2021. Fueron excluidos los duplicados y los que no incluían la temática abordada. Inicialmente, fueron identificados 29 artículos. Después de la aplicación de los criterios de inclusión y exclusión, resultaron 10 artículos para análisis. Resultados: De las complicaciones relacionadas al uso de la posición prona, 10 (100\%) de los estudios abordan la lesión por presión como la principal complicación de esta maniobra terapéutica. Con respecto a las estrategias de prevención, los estudios analizados citan el cambio de decúbito asociada al uso de apoyo e hidrocoloides como principales métodos preventivos. Conclusión: Fueron identificadas las siguientes estrategias de prevención de lesión por presión facial por el uso de posición prona: cambio de decúbito en tiempos preestablecidos; uso de dispositivos que proporcionan alivio de puntos de presión, tales como los apoyos e hidrocoloides; y la utilización de materiales de bajo costo y fácil acceso, como esponjas quirúrgicas adaptadas, respetando las estructuras anatómicas de cada paciente.
\end{abstract}

DESCRIPTORES: Decúbito ventral. Lesión por presión. Prevención de enfermedades. Estomaterapia.

\section{INTRODUCTION}

The prone position (PP) is a promising strategy to improve hypoxemia in patients with acute lung injury and acute respiratory distress syndrome (ARDS). During its application, there is ventilation of areas of the lung that are in collapse, accompanied by redistribution of blood flow and consequent improvement in the ventilation/ perfusion ratio ${ }^{1}$.

In view of the COVID-19 pandemic, and as a consequence of the hemodynamic instability of the patients, there was a need to opt for therapeutic methods that would improve the respiratory failure caused by the disease. One of these methods was the adoption of $\mathrm{PP}^{2}$.

However, the use of this position brought with it some complications, such as the high incidence of pressure injury (PI), which occurred in up to $80 \%$ of patients placed in a prone position for more than 16 hours a day ${ }^{2}$. A study conducted at MedStar Georgetown University Hospital and MedStar Washington Hospital Center, in the city of Washington, United States, between March 1 and July 26, 2020, found that 47.6\% of patients in PP developed facial PI. The most commonly affected site was the masseter, with a total of $84 \%$, followed by the ears, with $50 \%$. The mean duration of PP for patients who developed PI was 6.79 days $^{3}$.

According to the National Pressure Ulcer Advisory Panel (NPUAP), PI is localized damage to the skin and/or underlying tissue, regularly over a bony prominence. It is the result of pressure or even its combination with shear 
resulting from friction ${ }^{4}$. In the Intensive Care Units (ICU) of Brazil, the prevalence of PI varies between $35.2 \%$ and $63.6 \%$ and the incidence between $11.1 \%$ and $64.3 \%$.

The nursing team plays an important role in the prevention of PI in the hospital, using preventive measures. For this, the health education of these professionals must be constant, as it is an essential tool to develop quality nursing care ${ }^{6}$.

Assessing the risk of developing PI is essential for planning and implementing prevention and treatment strategies for these injuries. Adequate monitoring must be carried out in order to correctly establish treatment measures and improvement in care ${ }^{7}$.

Given the context of high incidence of PI cases caused by the use of PP, the following guiding question emerged: what are the facial PI prevention strategies used in patients under PP? Thus, this study aims to identify in the literature the main strategies used by the nursing staff to prevent facial PI caused by the use of PP.

\section{METHODS}

An integrative literature review was used, a research method that allows the search, synthesis and critical evaluation of available evidence on an investigated topic, and which results in knowledge of the researched theme ${ }^{8}$.

The research problematic was constituted according to the Population Interest Context (PICo) strategy. The following structure was reached: $\mathrm{P}$ - patients with facial lesions; I - pressure injury prevention; Co - prone position. Therefore, the following research problem was formulated: what are the facial PI prevention strategies used in patients on PP?

The listing of the data was carried out during the month of March 2021, through an advanced search in PubMed and in Biblioteca Virtual de Saúde (BVS), in the following databases: Medical Literature Analysis and Retrieval System Online (MEDLINE), Literatura Latino-Americana e do Caribe (LILACS), Base de Dados de Enfermagem (BDENF) and Índice Bibliográfico Espanhol de Ciências de Saúde (IBECS).

The inclusion criteria used were: a) primary articles that presented the nursing strategies for the prevention of PI in patients who use PP as a phenomenon of interest; b) articles published in English, Portuguese and Spanish; c) complete articles available in full; and d) articles published between 2016 and 2021. Exclusion criteria were: a) editorials, theses, dissertations and integrative review articles; $b$ ) repeated articles and those that did not answer the research question.

The search strategy used was composed of descriptors belonging to the Medical Subject Headings (MeSH) or its analogues, available in the Descritores em Ciências da Saúde (DeCS), namely: "prone position", "pressure injury" and "disease prevention", used in Portuguese and English, according to the database, with the terms combined by means of the Boolean operator AND.

The search was carried out by three independent researchers, simultaneously. The sequence of use of descriptors and crossings in each database was standardized, and then the results obtained were compared. The articles in the sample were selected according to the sequence: a) title reading; b) summary reading; and c) reading the full text. In cases where there were disagreements, there was discussion between the three evaluators, and subsequent analysis by a fourth evaluator to reach a consensus.

The level of evidence was determined according to the following classification: level I - meta-analysis of controlled and randomized studies; level II - experimental study; level III -quasi-experimental study; level IV descriptive/non-experimental study or with a qualitative approach; level V - case report or experience; level VI consensus and expert opinion'.

Thus, 29 publications were detected, of which, after applying the inclusion and exclusion criteria, 10 were selected for the sample of this review. No other studies were included after the manual search process. For selection of publications, the recommendations of the Preferred Reporting Items for Systematic Reviews and Meta-Analyses (PRISMA $)^{10}$ were followed, according to Fig. 1. 


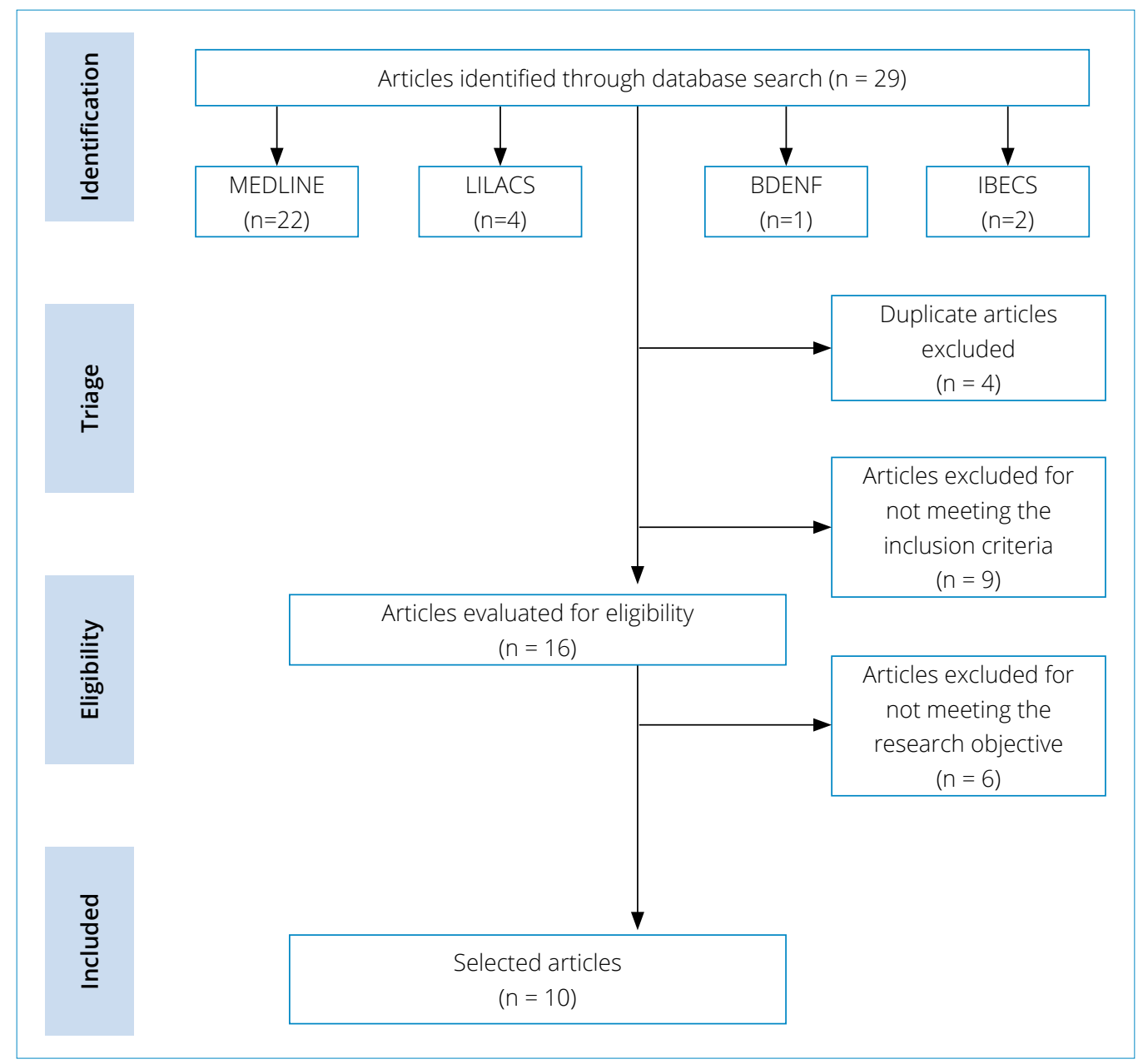

Figure 1. Selection flowchart of primary studies. Teresina (PI) - 2021.

\section{RESULTS}

Ten studies were selected to elaborate the results, 2 (20\%) of the articles were in LILACS; 1 (10\%) in IBECS; and 7 (70\%) on MEDLINE. Among those chosen, 1 (10\%) was published in magazines that address different themes; 8 (80\%) published in nursing journals that focus mainly on publications aimed at stomatherapy; and $1(10 \%)$ in a specific journal that had dermatological issues as its main theme.

Based on the general analysis carried out in the selected studies, it was concluded that 7 (70\%) of the studies were published in 2020; 1 (10\%) in the year 2019; 1 (10\%) in the year 2017; and 1 (10\%) in 2016. Among these works, the international ones stand out, with the highest rate of publications, which totaled $8(80 \%)$ of the selected articles. In the case of nationals, 2 (20\%). As for the countries of origin of international articles, 5 (50\%) were carried out in the United States; 1 (10\%) in France; 1 (10\%) in Italy; and 1 (10\%) in Spain. Of the national articles, 1 (10\%) was carried out in Porto Alegre; and $1(10 \%)$ in São Paulo.

Regarding methodology, 8 (80\%) of the studies used the qualitative approach, and only 2 (20\%) used the mixed approach. As for the level of evidence, 9 (90\%) of them used level IV, which deals with the descriptive/non-experimental study or qualitative approach, and $1(10 \%)$ study used the level of evidence $V$, which deals with the case report or experience.

Regarding the profile of patients for the indication of the prone position as a therapeutic method, and, consequently,


patients with respiratory distress syndrome using mechanical ventilation. Of the complications related to the use of $\mathrm{PP}, 10$ (100\%) studies address PI as the main complication of this therapeutic maneuver. 
With regard to prevention strategies, 10 (100\%) studies cite the change of position associated with the use of pads and hydrocolloids as the main preventive methods. However, other methods were mentioned that also had an effect on the prevention of facial PI, as shown in Table 1.

Table 1. Summary of review articles by author/year, prevention strategies and outcome. Teresina (PI) - 2021.

\begin{tabular}{|c|c|c|}
\hline Author / Year & Prevention Strategies & Outcome \\
\hline $\begin{array}{l}\text { Martel }^{11} \\
\text { et al, } 2020\end{array}$ & $\begin{array}{l}\text { Cushion use, daily skin hydration, keeping the skin } \\
\text { away from moisture, changing position after using the } \\
\text { prone position. }\end{array}$ & $\begin{array}{l}\text { It was found that standard nursing care, which is } \\
\text { already used in the intensive care environment, } \\
\text { provides great results in the prevention of pressure } \\
\text { injuries. }\end{array}$ \\
\hline $\begin{array}{l}\text { Perrillat } 22 \\
\text { et al, } 2020\end{array}$ & $\begin{array}{l}\text { Insertion of a prone position protocol lasting at least } \\
12 \text { hours, divided into decubitus change sessions, the use } \\
\text { of devices such as a cushion and the maintenance } \\
\text { of hydrated skin. }\end{array}$ & $\begin{array}{l}\text { It was noted that, with the adoption and application } \\
\text { of the prone position protocol and other basic } \\
\text { measures, there was a substantial reduction in } \\
\text { pressure injury cases. }\end{array}$ \\
\hline $\begin{array}{l}\text { Moore }{ }^{19} \\
\text { et al, } 2020\end{array}$ & $\begin{array}{l}\text { Use of positioning devices such as a cushion to contain } \\
\text { the charge from pressure points on the face and body, } \\
\text { use of hydrocolloids and decubitus change. }\end{array}$ & $\begin{array}{l}\text { It is concluded that the use of positioning devices, } \\
\text { such as the cushion, is a useful addition within an } \\
\text { overall pressure injury prevention strategy. }\end{array}$ \\
\hline $\begin{array}{l}\text { Ramondetta }{ }^{12} \\
\text { et al, } 2020\end{array}$ & $\begin{array}{l}\text { Change of position every } 2 \text { hours, daily skin hydration, } \\
\text { use of hydrocolloids, use of a cushion on the face. }\end{array}$ & $\begin{array}{l}\text { It was noticed that the adoption of simple and } \\
\text { common strategies had great results in the } \\
\text { prevention of facial pressure injuries. }\end{array}$ \\
\hline $\begin{array}{l}\text { Lucchini18 }^{18} \\
\text { et al, } 2020\end{array}$ & $\begin{array}{l}\text { Use of a softer and more specific head cushion, } \\
\text { with space for the breathing tube, better distribution } \\
\text { of pressure points across the face, or silicone gels, } \\
\text { silicone foam dressings, change of position when the } \\
\text { patient is stable. }\end{array}$ & $\begin{array}{l}\text { It was found that the use of a cushion to relieve } \\
\text { pressure points, together with the change in } \\
\text { decubitus, led to a reduction in cases of facial } \\
\text { pressure injuries. }\end{array}$ \\
\hline $\begin{array}{l}\text { Busnardo² } \\
\text { et al, } 2020\end{array}$ & $\begin{array}{l}\text { Adoption of material for the daily routine in all patients, } \\
\text { such as the use of pillows to relieve pressure points, } \\
\text { establishment of a protocol for changing positions. }\end{array}$ & $\begin{array}{l}\text { It was inferred that the adoption of the materials on } \\
\text { a daily basis significantly reflected in the reduction } \\
\text { of pressure injury cases. }\end{array}$ \\
\hline $\begin{array}{l}\text { Stubington }{ }^{20} \\
\text { et al, } 2020\end{array}$ & $\begin{array}{l}\text { Repositioning the head and using easily accessible } \\
\text { materials, such as surgical sponges on the nose and } \\
\text { face, in order to protect the most affected areas in the } \\
\text { prone position. }\end{array}$ & $\begin{array}{l}\text { It was noticed that the use of low-cost materials, } \\
\text { such as surgical sponges, can reduce the incidence } \\
\text { of pressure injuries induced by the prone position } \\
\text { on the face and nose. }\end{array}$ \\
\hline $\begin{array}{l}\text { Welter }{ }^{21} \\
\text { et al, } 2019\end{array}$ & $\begin{array}{l}\text { Daily hydration of the skin and air mattress, in addition to } \\
\text { the use of hydrocolloid dressings at the points of greatest } \\
\text { risk of pressure injury, the use of pillows for positioning. }\end{array}$ & $\begin{array}{l}\text { It was concluded that with the care already known } \\
\text { by the team, such as the use of an air mattress, the } \\
\text { use of hydrocolloids and daily skin hydration, the } \\
\text { pressure injury rates decreased. }\end{array}$ \\
\hline
\end{tabular}

There should be regular changes in the position of the head, and the position of the breathing tube should

Ponseti ${ }^{17}$

et al, 2017 be changed between each prone position session. The circumferential fixation must be protected with gauze or replaced by a specific endotracheal tube support, equipped with a silicone protection when in contact with the cheek and labial commissure.
It was found that the main method to prevent facial pressure injuries would be regular changes in head position, which demonstrated a reduction in pressure injury cases.
$\mathrm{Kim}^{23}$
et al, 2016
Cut pieces of silicone foam dressing on forehead, cheeks, corners of lips, chin and under nose.

The use of soft silicone foam dressings can prevent the development of deep facial tissue lesions in patients receiving prolonged prone therapy. 


\section{DISCUSSION}

PP is a very effective therapeutic method in the diversity of pathologies related to respiratory distress, especially in the COVID-19 pandemic, which brought an unprecedented challenge to health. Among the multiple challenges associated with this are the prolonged placement of the patient in the prone position and the use of respiratory support equipment, which has increased the risk of PI related to medical devices ${ }^{11}$.

An example of this are patients undergoing treatment for COVID-19 who present ARDS when undergoing tracheal intubation and prone positioning cycles for five days. As a result, they may present multiple ulcerative lesions on the face, particularly on the chin and nostrils, attributable to the pressure exerted by the devices used for mechanical ventilation, especially during $\mathrm{PP}$ sessions ${ }^{12}$.

PI is observed as the main complication of the prone position, in which the most affected regions are those of bony prominences. Patients with hemodynamic and/or respiratory instability treated in the ICU have a clinical picture of increased risk of PI due to the use of vasoactive drugs, sedation and invasive mechanical ventilation ${ }^{13,14}$.

In addition to PI, PP increases the risk of facial edema, transient hemodynamic instability, corneal abrasions and orotracheal tube obstruction. Due to the risk of complications caused by this position, it is necessary that health professionals have safety and training for the management of this patient, both in the proper technique for prone and in PI control precautions and in infection control in case of accidental disconnection of the orotracheal tube ${ }^{15,16}$.

In order to identify the incidence of serious complications recorded and possible factors related to treatment in the prone position, a study was carried out in the adult ICU of a hospital in Spain, with a diagnosis of ARDS treated with PP. The only serious complication recorded was PI, with an incidence of $25.7 \%$. The possible factor related to PI was the greater number of hours of PP in patients who developed PI. It was also observed that when the nutritional contribution was adequate, there was a lower incidence of $\mathrm{PI}^{17}$.

In a second study, to identify the main risk factors for the development of PI, patients were divided into two groups: patients with lesions and patients without PI due to prone. When comparing the two groups, there was a statistically significant difference for the following risk factors: duration of the PP session, total number of PP sessions, and, consequently, the total time spent in $\mathrm{PP}^{18}$.

According to the articles above, the biggest complication of PP is PI caused by medical devices. Thus, there is a need for greater attention to these patients, as well as preventive strategies designed by the nursing staff to avoid this type of complication.

\section{Pressure injury prevention strategies in patients with COVID-19}

The prevention of PI requires daily inspection of hygiene as well as the state of hydration, control of moisture and skin temperature, in addition to reducing pressure on bony prominences. For this, it is necessary to change the position every 2 hours. However, the serious condition in which patients find themselves makes difficult this type of action ${ }^{2}$.

Individuals placed on PP are at increased risk of developing facial PI. Current evidence suggests that positioning devices to discharge the load from pressure points on the face and body are a useful addition within the overall PI prevention strategy ${ }^{19}$.

The use of surgical foams is a simple technique used to relieve pressure and prevent facial PI. It is low cost and easily accessible material. They can be cut and adjusted according to the needs of each patient, reducing the incidence of injuries induced by treatment in prone ${ }^{20}$.

A university hospital, with five years of experience in standardizing PP, aimed to identify the occurrence of PI in prone patients. As a result of the study, the low incidence of PI was obtained, concluding that this result was a consequence of the adoption of the following preventive strategies: daily skin hydration, use of an air mattress, use of hydrocolloid dressings at the highest risk points for PI, use of cushions for positioning, in addition to the standardization of nursing care, the use of checklists and, finally, specific training for the team that attends to this type of patient ${ }^{21}$. 
In a similar study, they analyzed two cases aiming to emphasize the risk of PI on the face in the prone position, in addition to highlighting the importance of adequate preventive actions. In case 1, the patient was male, 27 years old, morbidly obese. Case 2 was a 50-year-old patient with no comorbidity. Both patients were admitted to the ICU for treatment through mechanical ventilation due to COVID-19. The two patients followed the PP protocol lasting at least 12 hours each, but the first had 6 sessions, the second 9 sessions ${ }^{22}$.

In the first case studied, during the protocol, several facial PI (NPUAP stage 2 and 3) occurred on the right side of the face. The patient had keratitis and a corneal ulcer in the right eye. In addition, the use of an inappropriate cushion resulted in pressure on the patient's cheek next to the masseter. In the second case, the patient had PI (NPUAP stage 2) on the left cheek and on the left labial commissure, under the tape used to secure the breathing tube ${ }^{22}$.

To avoid these complications, there are some strategies: a) the intensive care team must be trained; b) the PP must be supervised; c) regular changes in head position are necessary during each PP session, and the breathing tube position must be changed between each PP session; d) the circumferential fixation must be protected with gauze or replaced by a specific endotracheal tube support, equipped with a silicone protection in contact with the cheek and labial commissure; and e) use of a softer and more specific head cushion, with space for the breathing tube, better distribution of pressure points across the face or silicone gels or silicone foam dressings ${ }^{22}$.

Patients infected with COVID-19 who did not receive PI preventive measures developed multiple necrotic facial lesions related to prone positioning during treatment. Those who were previously treated with a prophylactic dressing, cut pieces of silicone-based foam dressing applied to the forehead, cheeks, corner of lips, chin and under the nose did not develop PI during prone therapy ${ }^{23}$.

Nursing, in this context, must pay attention frequently and critically reflect on its action. It must be dynamic, creative and proactive, as it is observed in the aforementioned studies that when creativity was combined with specific preventive strategies and put into practice, the result was a low incidence of PI in patients.

One of the limitations of this study was the lack of research related to the prevention of facial PI in patients treated in PP, since, in most of the studies found, interventions were aimed at preventing PI in other settings. Thus, it is expected that this work can contribute to the reflection of academics and nursing professionals about this theme and it is recommended that further research be carried out.

\section{CONCLUSION}

Strategies for the prevention of facial PI in patients undergoing PP are a set of attitudes that must be taken in advance, so that they arise in order to prevent complications. The most common in the studies in question were the change of decubitus at pre-established times and the use of devices that provide relief from pressure points, such as pads and hydrocolloids.

Thus, it is important that these preventive strategies are carried out more constantly, and that they are adopted as a routine in health services, especially in ICUs. Visibility should also be given to strategies that are little seen, such as the use of low-cost and easily accessible materials, such as adapted surgical sponges, respecting the anatomical structures of each patient. Therefore, it is suggested to carry out more training for professionals from the entire team, in which the focus should be on the introduction and practice of preventive and strategic actions in health services.

\section{AUTHORS' CONTRIBUTION}

Conceptualization: Bandeira LLM e Carvalho SMO; Research: Bandeira LLM e Carvalho SMO; Methodology: Calaça LRR e Rabelo GMS; Writing - First version: Bandeira LLM e Carvalho SMO; Writing - Reviewing \& Editing: Barbosa WCF e Machado BAS; Supervision: Silva JS. 


\title{
DATA STATEMENT AVAILABILITY
}

All dataset were generated and analyzed in the current study.

\author{
Prezado autor, \\ Ok utilizar esse texto?
}

\section{FUNDING}

Not applicable.

\section{ACKNOWLEDGMENTS}

Not applicable.

\section{REFERENCES}

1. Benjamin MF, Santos AC, Salvador AC, Jorge MA. Posição prona em unidade de terapia intensiva. Revista UNILUS Ensino e Pesquisa. 2018 [cited 2021 Mar 28];15(40):77-83. Available at: http://revista.lusiada.br/index.php/ruep/article/view/977/ u2018v15n40e977

2. Busnardo FF, Monteiro GM, Mendes RR, Abbas L, Pagotto VF, Camargo C et al. A multidisciplinary approach to prevent and treat pressure sores in proned COVID-19 patients at a quaternary university hospital. Clinics. 2020;75:e2196. https://doi. org/10.6061/clinics/2020/e2196

3. Shearer SC, Parsa KM, Newark A, Peesay T, Walsh AR, Fernandez S et al. Facial pressure injuries from prone positioning in the COVID-19 era. Laryngoscope. 2020;131(7):E2139-E2142. https://doi.org/10.1002/lary.29374

4. National Pressure Ulcer Advisory Panel (US); European Pressure Ulcer Advisory Panel; Pan Pacific Pressure Injury Alliance. Prevention and treatment of pressure ulcers: quick reference guide. Haesler E, editor. Australia: Cambridge Media; 2014.72 p. Available at: http://medi-guide.meditool.cn/ymtpdf/7D604C9A-DC46-5665-E57B-EB4BEF621213.pdf

5. Vasconcelos JM, Caliri MH. Ações de enfermagem antes e após um protocolo de prevenção de lesões por pressão em terapia intensiva. Esc Anna Nery. 2017 [cited 2021 Mar 27];21(1):e20170001. https://doi.org/10.5935/1414-8145.20170001

6. Sousa MM, Neiva MJLM, Silva MFN, Vieira JL, Melo MF, Reis EM et al. Cuidados de enfermagem na prevenção às lesões por pressão em pacientes hospitalizados. Braz J Hea Rev 2019;2(5):4336-44. https://doi.org/10.34117/bjhrv2n5-036

7. Olkoski E, Assis GM. Aplicação de medidas de prevenção para úlceras por pressão pela equipe de enfermagem antes e após uma campanha educativa. Esc Anna Nery. 2016;20(2)363-9. https://doi.org/10.5935/1414-8145.20160050

8. Mendes KS, Silveira RC, Galvão CM. Revisão integrativa: método de pesquisa para a incorporação de evidências na saúde e na enfermagem. Texto Contexto - Enferm. 2008; 17(4):758-64 apud Sousa LM, Marques-Vieira CM, Severino SS, Antunes AV. A metodologia de revisão integrativa da literatura em enfermagem. RIE. 2017[cited 2021 Mar 29];21(2):20. Available at: http:// www.sinaisvitais.pt/images/stories/Rie/RIE21.pdf\#page=17

9. Melnyk BM, Fineout-Overholt E. Evidence-based practice in nursing and healthcare: a guide to best practice. Philadelphia (PA): Lippincott Williams \& Wilkins; 2005. p.3-24.

10. Moher D, Liberati A, Tetzlaff J, Altman DG, Prisma Group. Preferred reporting items for systematic reviews and meta-analyses: the PRISMA statement. PLoS Med. 2009;6(7):e1000097. https://doi.org/10.1371/journal.pmed.1000097

11. Martel T, Orgill DP. Medical Device-Related Pressure Injuries During the COVID-19 Pandemic. J Wound Ostomy Continence Nurs. 2020;47(5):430-4. https://doi.org/10.1097/WON.0000000000000689

12. Ramondetta A, Ribero S, Costi S, Dapavo P. Pression-induced facial ulcers by prone position for COVID-19 mechanical ventilation. Dermatologic Therapy. 2020;33(4):e13748. https://doi.org/10.1111/dth.13748

13. Daniel LB, Gabriel VGR, Flávio MDA, Rapello GVG, Andrade FMD. Posição prona no tratamento da insuficiência respiratória aguda na Covid-19. ASSOBRAFIR [Internet] 2020. [cited 2021 Mar 16]. Available from: https://assobrafirciencia.org/article/ doi/10.47066/2177-9333.AC20.covid19.011

14. Souza MFC. Risco de lesão por pressão em UTI: adaptação transcultural e confiabilidade da EVARUCI. Acta Paul Enferm. 2018;31(2):201-8. https://doi.org/10.1590/1982-0194201800029

15. Alhazzani W, Møller MH, Arabi YM, Loeb M, Gong MN, Fan E et al. Surviving Sepsis Campaign: guidelines on the management of critically ill adults with Coronavirus Disease 2019 (COVID-19). Intensive Care Med. 2020;46(5):854-87. https://doi.org/10.1007/ s00134-020-06022-5 
16. Oliveira VM, Piekala DM, Deponti GN, Batista DCR, Minossi SD, Chisté M et al. Checklist da prona segura: construção e implementação de uma ferramenta para realização da manobra de prona. Rev Bras Ter Intensiva. 2017;29(2):131-41. https:// doi.org/10.5935/0103-507X.20170023

17. Ponseti EJ, Millán AV, Chinchilla DO. Análisis de las complicaciones del decúbito prono en el síndrome de distrés respiratorio agudo: estándar de calidad, incidencia y factores relacionados. Enferm Intensiva. 2017;28(3):125-34. https://doi.org/10.1016/j. enfi.2016.12.003

18. Lucchini A, Bambi S, Mattiussi E, Elli S, Villa L, Bondi $\mathrm{H}$ et al. Prone position in acute respiratory distress syndrome patients: a retrospective analysis of complications. Dimens Crit Care Nurs. 2020;39(1):39-46. https://doi.org/10.1097/ DCC.0000000000000393

19. Moore Z, Patton D, Avsar P, McEvoy NL, Curley G, Budri A et al. Prevention of pressure ulcers among individuals cared for in the prone position: lessons for the COVID-19 emergency. J Wound Care. 2020;29(6):312-20. https://doi.org/10.12968/ jowc.2020.29.6.312

20. Stubington TJ, Mansuri MS. Novel technique using surgical scrub sponges to protect the nose and face during prone ventilation for coronavirus disease 2019. J Laryngol Otol. 2020; 134(8):735-8. https://doi.org/10.1017/S0022215120001590

21. Weller DI, Batista DCR, Moretti MMS, Piekala DM, Oliveira VM, Carleti M. Perfil clínico e complicações em pacientes pronados: uma coorte de um hospital universitário. Clin Biomed Res. 2019;39(4):301-6. https://doi.org/10.22491/2357-9730.96420

22. Perrillat A, Foletti J-M, Lacagne A-S, Guyot L, Graillon N. Facial pressure ulcers in COVID-19 patients undergoing prone positioning: How to prevent an underestimated epidemic? J Stomatol Oral Maxillofac Surg. 2020;121(4):442-4. https://doi. org/10.1016/j.jormas.2020.06.008

23. Kim RS, Mullins K. Preventing Facial Pressure Ulcers in Acute Respiratory Distress Syndrome (ARDS). J Wound Ostomy Continence Nurs. 2016;43(4):427-9. https://doi.org/10.1097/WON.0000000000000247 